\title{
Developed foot drop as a complication of bariatric surgery: case reports
}

\author{
Déficit de dorsiflexão do tornozelo como complicação de cirurgia bariátrica: \\ relato de casos \\ Marcelo Pires Prado ${ }^{1}$
}

\begin{abstract}
Two cases of patients with morbid obesity submitted to bariatric surgery and with considerable weight loss are presented. During follow-up, they complained of weakness in the legs and the physical examination showed reduction of ankle dorsiflexion muscle strength (foot drop). In these cases, the symptoms subsided spontaneously. A literature review is presented.
\end{abstract}

Keywords: Ankle/injuries; Obesity, morbid; Bariatric surgery; Case reports

\section{RESUMO}

São descritos dois casos de pacientes com obesidade mórbida submetidos à cirurgia bariátrica e importante perda de peso subsequente. $\mathrm{Na}$ evolução, apresentaram queixa de fraqueza nas pernas e 0 exame físico revelou perda do ângulo de dorsiflexão do pé. Estes casos tiveram resolução espontânea. É apresentada a literatura a respeito.

Descritores: Tornozelo/lesões; Obesidade mórbida; Cirurgia bariátrica; Relatos de casos

\section{INTRODUCTION}

The epidemics of obesity and the limited efficacy of medical treatments have led to the increased number of bariatric surgical procedures for complicated obesity. Several different surgical procedures are used ${ }^{(1-4)}$. The rising rates of bariatric surgery are accompanied by neurological complications related to nutrient deficiencies. The preventable and potentially treatable nature of these complications makes them an important issue. Prognosis depends on prompt recognition and introduction of appropriate therapy.
The prevalence of neurological complications in bariatric surgery of two prior large studies were estimated at 5 and $16 \%{ }^{(5-6)}$. Orthopedic surgeons should be aware of this complication because those complaints are related to their field.

\section{CASE REPORT}

\section{Case 1}

S.F., a 49-year-old male patient, $1.82 \mathrm{~m}, 120 \mathrm{~kg}$, body mass index 36.2, was submitted to a gastroplasty with cholecistectomy, and lost $45 \mathrm{~kg}$ in 11 months. During the postoperative period, he complained of weakness in both legs and, upon physical examination, he presented reduced ankle dorsiflexion muscle strength that persisted for 45 days and resolved spontaneously.

\section{Case 2}

L.D.O., a 22-year-old female patient, $1.65 \mathrm{~m}, 108 \mathrm{~kg}$, body mass index 39.5 , was submitted to gastroplasty, and lost $38 \mathrm{~kg}$ in 6 months. In this period, she complained of weakness and difficultywalking. On physical examination, she had complete loss of right ankle dorsiflexion strength. She was submitted to a magnetic resonance imaging that showed no abnormalities. After three weeks, she returned with the right leg strength fully recovered.

\section{DISCUSSION}

The optimal functioning of the central and peripheral nervous systems depends on a constant supply of appropriate nutrients.

'MD, Orthopedic surgeon, Hospital Israelita Albert Einstein - HIAE, São Paulo (SP), Brazil.

Corresponding author: Marcelo Pires Prado - Avenida Albert Einstein, 627, Conj. 1204 - Morumbi - CEP 05651-901 - São Paulo (SP), Brazil - Tel.: $112151-5320$ - Ramal 43204 -

e-mail: mpprado@einstein.br

Received on Aug 17, 2009 - Accepted on May 10, 2010 
The B-group vitamins (vitamin $\mathrm{B}_{12}\left[\mathrm{~B}_{12}\right]$, thiamine, niacin, and pyridoxine), vitamin $\mathrm{E}$, copper, and possibly folic acid are particularly important for good functioning of the nervous system.

$\mathrm{B}_{12}$ deficiency is the most common nutritional deficiency noted after bariatric surgery ${ }^{(7-8)}$.

A low $\mathrm{B}_{12}$ level has been noted in $70 \%$ of patients undergoing gastric bypass surgery and $\mathrm{B}_{12}$ deficiency in nearly $40 \%^{(9)}$. It may result from inadequate intake, impaired hydrolysis of $\mathrm{B}_{12}$ from dietary protein, or abnormal IF and $\mathrm{B}_{12}$ interaction. $\mathrm{B} 1$ deficiency is frequently seen ${ }^{(5)}$.

$\mathrm{B}_{1}$ deficiency after bariatric surgery is the result of intractable vomiting, rapid weight loss, and inadequate vitamin repletion and associated neurological complications due to $\mathrm{B}_{1}$ deficiency ${ }^{(10-11)}$.

Thiamine deficiency may be seen with persistent vomiting, anorexia nervosa, dieting, malnutrition, severe gastrointestinal or liver disease, gastrointestinal surgery (including bariatric surgery), and AIDS.

Copper deficiency is increasingly recognized after gastric surgery (for peptic ulcer disease or bariatric surgery $)^{(12-13)}$.

Neurological complications may be noted in 5 to $16 \%$ of patients undergoing surgery for obesity ${ }^{(14)}$.

Central and peripheral neurological complications often present multifactor etiology; that is, they may be associated with rapid weight loss and could be due to a deficiency of a vitamin called thiamine. The delayed presentation of neurological complications is more common.

Neurological complications following weightreduction surgery can involve most parts of the nervous system $^{(15)}$.

A recent review of reported cases of neurological complications of bariatric surgery identified 96 patients $^{(16)}$. Lumbar plexopathy or radiculopathy were rare and each seen in one case only.

In a controlled retrospective study of peripheral neuropathy after bariatric surgery, peripheral neuropathy developed in 71 of 435 patients: sensorypredominant polyneuropathy in 27 , mononeuropathy in 39 , and radiculoplexopathy in $5^{(17-18)}$.

Risk factors for neurological complications include rate and absolute amount of weight loss, prolonged gastrointestinal symptoms, not attending a nutritional clinic after bariatric surgery, less vitamin and mineral supplementation, reduced serum albumin and transferrin, postoperative surgical complications requiring hospitalization, and having jejunoileal bypass. In a series of 23 patients who had neurological complications associated with bariatric surgery, protracted vomiting was noted in all affected patients ${ }^{(5)}$.
Our patients developed mononeuropathy without any changes in blood tests, even vitamins and minerals dosage.

A long-term follow-up with dietary counseling is important. All bariatric surgery patients should have 6-month follow-up laboratory studies that include complete blood count, serum iron, iron-binding capacity, $\mathrm{B}_{12}$, calcium, and alkaline phosphatase ${ }^{(19)}$.

Neurological sequelae may take months to resolve, and residual neurological impairment can result even in cases in which the treatment is promptly administered. Delayed treatment can lead to permanent neurological impairment ${ }^{(20)}$.

It is unclear which patients may develop copper deficiency after gastric surgery and if routine screening and supplementation should be considered. Oral supplementation containing the RDA for micronutrients can prevent abnormal blood indicators of most vitamins and minerals but are insufficient to maintain normal plasma $\mathrm{B}_{12}$ levels in approximately $30 \%$ of gastric bypass patients ${ }^{(19)}$.

The neurological complications of bariatric surgery involve most parts of the nervous system and frequently more than one.

Physicians who care for patients after bariatric surgeryshould bevery aware of neurologic complications. Attention should be given to vitamins and mineral supplements to prevent some of these complications and to avoid severe and rapid weight loss ${ }^{(21)}$.

Rapid weight loss, recurrent vomiting, and inadequate supplementation of key nutrients predispose to the development of neurological complications.

Of 435 patients who had bariatric surgery of the cases of Thaisetthawatkul et al., two patients presented peroneal neuropathy at the fibula head; one patient had lateral femoral cutaneous neuropathy, and one patient had sciatic neuropathy. In the mononeuropathy group, the etiology may not be different from usual mononeuropathies in which mechanical compression and entrapment appear to play a role ${ }^{(22)}$.

Literature review yielded 50 case reports of 96 patients with neurological symptoms after bariatric procedures. There was only one case of foot drop ${ }^{(16)}$.

Among 78 patients submitted to bariatric surgery, 9 developed foot drop after bariatric surgery. The mean weight loss for these patients was $45 \mathrm{~kg}$. Weight reduction took place during a mean period of 8.6 months. We demonstrated that significant weight loss is correlated with a higher risk to develop foot drop and that the time period in which the weight loss is achieved is important. A rapid reduction of body weight is correlated with a higher risk to develop drop foot $^{(23)}$. 


\section{REFERENCES}

1. Brolin RE. Bariatric surgery and long-term control of morbid obesity. JAMA. 2002;288(22):2793-6.

2. Buchwald H, Buchwald JN. Evolution of operative procedures for the management of morbid obesity 1950-2000. Obes Surg. 2002;12(5): 705-17.

3. Deitel M, Shikora SA. The development of the surgical treatment of morbid obesity. J Am Coll Nutr. 2002;21(5):365-71. Review.

4. Livingston EH. Obesity and its surgical management. Am J Surg. 2002;184(2):103-13.

5. Abarbanel JM, Berginer VM, Osimani A, Solomon H, Charuzi I. Neurologic complications after gastric restriction surgery for morbid obesity. Neurology. 1987;37(2):196-200.

6. Thaisetthawatkul P, Collazo-Clavell ML, Sarr MG, Norell JE, Dyck PJB. A controlled study of peripheral neuropathy after bariatric surgery. Neurology. 2004;63(8):1462-70.

7. Crowley LV, Olson RW. Megaloblastic anemia after gastric bypass for obesity. Am J Gastroenterol. 1983;78(7):406-10.

8. Crowley LV, Seay J, Mullin G. Late effects of gastric bypass for obesity. Am J Gastroenterol. 1984;79(11):850-60.

9. Amaral JF, Thompson WR, Caldwell MD, Martin HF, Randall HT. Prospective hematologic evaluation of gastric exclusion surgery for morbid obesity. Ann Surg. 1985;201(2):186-93.

10. Chaves LC, Faintuch J, Kahwage S, Alencar F de A. A cluster of polyneuropathy and Wernicke-Korsakoff syndrome in a bariatric unit. Obes Surg. 2002;12(3):328-34.
11. Sola E, Morillas C, Garzon S, Ferrer JM, Martín J, Hernández-Mijares A. Rapid onset of Wernickes encephalopathy following gastric restrictive surgery. Obes Surg. 2003;13(4):661-2.

12. Kumar N, McEvoy KM, Ahlskog JE. Myelopathy due to copper deficiency following gastrointestinal surgery. Arch Neurol. 2003;60(12):1782-5.

13. Kumar N, Ahlskog JE, Gross JB JR. Acquired hypocupremia after gastric surgery. Clin Gastroenterol Hepatol. 2004;2(12):1074-9.

14. Chang CG, Adams-Huet B, Provost DA. Acute post-gastric reduction surgery (APGARS) neuropathy. Obes Surg. 2004;14(2):182-9.

15. Berger JR. The neurologic complications of bariatric surgery. Arch Neurol. 2004;61(8):1185-9.

16. Koffman BM, Greenfield LJ, Ali II, Pirzada NA. Neurologic complications after surgery for obesity. Muscle Nerve. 2006;33(2):166-76.

17. Brolin RE. Gastric bypass. Surg Clin North Am. 2001;81(5):1077-95. Review.

18. Gollobin C, Marcus WY. Bariatric beriberi. Obes Surg. 2002;12(3):309-11.

19. Kumar N. Nutritional neuropathies, neurologic clinics. Philadelphia: W. B. Saunders Company; 2007

20. Juhasz-Pocsine K, Rudnicki SA, Archer RL, Harrik SI. Neurologic complications of gastric bypass surgery for morbid obesity. Neurology. 2007;68(21):1843-50.

21. Kumar N, Spencer DC, Karceski S. Obesity surgery: a word of neurologic caution Neurology. 2007;68(21):E36-8.

22. Thaisetthawatkul P, Collazo-Clavell ML, Sarr MG, Norell JE, Dyck PJB. A controlled study of peripheral neuropathy after bariatric surgery. Neurology.2004;63(8):1346-7.

23. Weyns FJ. Foot drop as a complication of weight loss after bariatric surgery: is it preventable? Obes Surg. 2008;17(9):1209-12. 